\title{
KEKERASAN FISIK DAN PSIKOLOGIS PADA NARAPIDANA LANSIA DI LEMBAGA PEMASYARAKATAN JAWA BARAT
}

\author{
Adiansyah*, Sukihananto \\ Fakultas Ilmu Keperawatan Universitas Indonesia, Depok 16424, Indonesia \\ *E-mail: adiansyah.numbone@gmail.com
}

\begin{abstract}
Abstrak
Lansia merupakan kelompok rentan dengan berbagai risiko kesehatan. Kelompok rentan lebih mudah terpapar masalah kesehatan, salah satunya adalah kekerasan fisik dan psikologis. Kelompok rentan yang berada dalam tempat berisiko, salah satu tempat berisko adalah lemabaga pemasyarakatan. Penelitian ini bertujuan untuk mengetahui gambaran kekerasan fisik dan psikologis pada narapidana lansia di lembaga pemasyarakatan Jawa Barat. Penelitian menggunakan sampel total berjumlah 36 responden yang terdapat di tiga lembaga pemasyarakatan. Instrumen penelitian merujuk pada Hwalek-Sengstock Elder Abuse Screening Test (H-S/EAST) dengan menggunakan skala likert. Hasil penelitian menunjukkan bahwa kekerasan fisik yang terjadi di lembaga pemasyarakatan sebesar 41,67\% dan kekerasan psikologis $36,11 \%$. Suku Sunda adalah suku yang mengalami kekerasan fisik dan psikologi paling besar dibandingkan dengan suku lainnya. Hasil penelitian merekomendasikan perawat, psikolog dan petugas lapas untuk bekerjasama dalam melakukan pencegahan kekerasan fisik dan psikologis, serta meningkatkan sarana keagamaan dan spiritual sebagai koping yang dilakukan oleh narapidana lansia.
\end{abstract}

Kata kunci: kekerasan fisik, kekerasan psikologis, lansia, lembaga pemasyarakatan.

\begin{abstract}
Physical and psychological violence at the Penitentiary Convicts Elderly in West Java. Aging process causing elderly to become one of the vulnerable groups. Vulnerable groups are susceptible to health problems, including physical and psychological abuse. Penitentiaries is one of vulnerable places that causes elderly as a vulnerable groups. This study aimsto describe physical and psychological abuse on elderly inmates in West Java Penitentiaries.This study was conducted at three penitentiaries in West Java with 36 respondents using Hwalek-Sengstock Elder Abuse Screening Test (H-S/EAST) instrument. The result showed that physical abuse $41.67 \%$ and psychological abuse $36.11 \%$. Sundanese is one of ethnic groups that showed the biggest percentage of elderly physical and psychological abuse among the other ethnics. Nurses, psychiatrist, and penitentiary officers need to prevent physical and psychological abuse together. Furthermore, nurses need to optimize spiritual and religious activities as a coping mechanism among elderly inmates.
\end{abstract}

Keywords: physical abuse, psychological abuse, elderly, penitentiaries.

\section{Pendahuluan}

Jumlah lanjut usia (lansia) di Indonesia setiap tahun mengalami peningkatan. Data Kementerian Kesehatan RI (2013) menyebutkan jumlah lansia tahun 2010 mencapai 23,99 juta atau 9, $77 \%$ dari total keseluruhan penduduk Indonesia. Peningkatan jumlah lansia ternyata masih belum berbanding lurus dengan kesejahteraannya. Jumlah lansia terlantar di Indonesia mencapai 1.549.201. Jawa Barat berada pada pe- ringkat kedua jumlah terlantar terbanyak di Indonesia yaitu mencapai 232.312 (Pusat Data dan Informasi, 2008). Keigher (1991) melakukan penelitian dengan hasil bahwa lansia terlantar menjadi korban kriminal tinggi. Penelitian lain yang dilakukan Eckeret dan Repaci pada 1997 menyebutkan 10-20\% lansia di atas 60 tahun berisiko tinggi mengalami kekerasan.

Lansia merupakan individu yang termasuk dalam kelompok rentan (Luoma, et al., 2011). 
Individu yang termasuk dalam kelompok rentan membutuhkan satu atau lebih kebutuhan lainnya yang berdampingan dengan pemenuhan kebutuhan dasar, seperti komunikasi, perawatan medis, pemeliharaan kebebasan, pengawasan dan transportasi. Kelompok rentan berhubungan dengan gabungan beberapa faktor sosial, personal, situasional dan lingkungan. Faktor-faktor tersebut dapat mengakibatkan peningkatan kerentanan terhadap kekerasan. Faktor lain yang menyebabkan seorang lansia menjadi kelompok rentan apabila tidak adanya kerabat dekat atau dukungan orang lain yang mampu dan bersedia untuk memberi bantuan (Miller, 2012).

Kekerasan fisik pada lansia adalah tindakan sengaja yang dilakukan untuk melawan kekuatan lansia sehingga menimbulkan nyeri fisik atau cedera (Singh, 2014). Tanda lansia yang mengalami kekerasan fisik adalah adanya memar, terdapat tanda jeratan tali atau benda tumpul atau tajam lainnya, tejadi cidera berulang kali tanpa alasan yang jelas, menolak untuk berobat (American Psychological Association, 2012). Kekerasan fisik biasanya diikuti dengan kekerasan psikologis (Lachs \& Pillemer, 1995). Kekerasan psikologis adalah seseorang yang dengan bebas mengancam, menghina, mentertawakan, mengabaikan, dan menteror lansia baik secara verbal maupun non verbal sehingga menyebabkan sakit hati, kesedihan yang mendalam atau stres (Singh, 2014; Luoma, et al., 2011).

Di Indonesia angka kekerasan fisik pada tahun 2009 sebesar 1,80\% (Komnas lansia, 2010). Data-data tersebut menunjukkan persentase kekerasan fisik saja tanpa jenis kekerasankekerasan lain sehingga prevalensi kekerasan pada lansia diprediksi akan semakin besar, itu berarti angka kekerasan lansia bagaikan "gunung es" yang sebenarnya banyak terjadi namun hanya sedikit terlihat.

Faktor risiko yang menyebabkan kekerasan pada lansia antara lain pelaku rawat, stres, isolasi sosial atau kurangnya hubungan sosial, keadaan lingkungan, hubungan kekeluargaan, dan menurunnya kesehatan mental (Benjamin \& Matthias, 2013; McDonald, 2011). Kekerasan pada lansia dapat terjadi di rumah, komunitas dan institusi (HealthLink BC, 2014). Tempat sosial berisiko tinggi terjadinya kekerasan pada lansia seperti ruangan di hotel, penginapan sementara atau asrama, jalan dan lembaga pemasyarakatan.

Lembaga pemasyarakatan menjadi tempat yang berisiko tinggi terhadap perilaku kekerasan fisik, psikologis, dan ekonomi pada lansia (Kosberg \& ACSW, 2008). Selain itu, lansia mengalami peningkatan masalah kesehatan fisik dan mental di lembaga pemasyarakatan (Keohane, Sed, Sterns, Lex, \& Sterns, 2008). Sistem Database Pemasyarakatan merilis pada 2014 terdapat 25 lembaga pemasyarakatan yang mengalami kelebihan kapasitas dari 33 lembaga pemasyarakatan yang ada di Indonesia. Lembaga pemasyarakatan (Lapas) di Indonesia membedakan lapas berdasarkan usia yang terdiri dari lapas anak-anak dan dewasa (Undang-Undang Nomor 12 tahun 1995), sehingga narapidana lansia bergabung dalam lapas dewasa. Hal tersebut dapat menjadikan faktor risiko terjadinya masalah pada narapidana lansia, seperti kekerasan, pemerasan, dan suap (Liwarti, 2013). Miller (2012) menyatakan bahwa kualitas hidup lansia terjadi apabila adanya penurunan kekerasan yang terjadi.

\section{Metode}

Jenis penelitian ini menggunakan metode penelitian kuantitatif dengan menggunakan desain penelitian deskriptif. Populasi dalam penelitian ini adalah narapidana lanjut usia di lembaga pemasyarakatan Bogor, Cibinong, dan Bekasi. Jumlah populasi narapidana lansia adalah 36 orang. Teknik pengambilan data dengan metode total sampling. Semua sampel dipilih jika memenuhi kriteria inklusi. Kriteria inklusi yang ditetapkan peneliti dalam memilih sampel pada penelitian ini adalah narapidana berusia 60 tahun atau lebih di lapas Bogor, Cibinong dan Bekasi; dan dapat berkomunikasi baik dengan 
bahasa Indonesia. Penelitian ini dilakukan mulai dari awal penyusunan proposal pada bulan Februari 2015 hingga akhir penyusunan laporan pada bulan Juni 2015.

\section{Hasil}

Tabel 1 menunjukkan bahwa narapidana lansia paling banyak berada pada kelompok umur lansia muda (60-69 tahun) sebanyak 77,78\% dan seluruhnya berjenis kelamin laki-laki atau $100 \%$. Narapidana lansia dari suku sunda adalah responden terbanyak sebesar $47,22 \%$.

Berdasarkan Tabel 2 menunjukkan bahwa narapidana lansia di lembaga pemasyarakatan mengalami kekerasan fisik sebesar 41,67\%. Berdasarkan Tabel 3 menunjukkan bahwa na- rapidana dengan kategori lansia tua lebih banyak terjadi kekerasan fisik $(62,5 \%)$. Hal ini berbanding terbalik dengan hasil kategori lansia muda yang angka kejadian kekerasan fisik lebih rendah $(35,71 \%)$.

Tabel 4 menunjukkan bahwa narapidana lansia dengan suku bangsa Tionghoa memiliki angka kekerasan fisik tertinggi yaitu sebesar $66,77 \%$. Berdasar Tabel 5 menunjukkan bahwa narapidana lansia di lembaga pemasyarakatan mengalami kekerasan psikologis sebesar 36,11\%.

Tabel 6 menunjukkan bahwa narapidana lan-sia tua lebih besar mengalami kekerasan psikologis $(37,5 \%)$. Tabel 7 menunjukkan narapidana lansia dengan suku bangsa Batak memiliki angka kekerasan psikologis tertinggi (50\%).

Tabel 1. Karakteristik Responden

\begin{tabular}{lcc}
\hline Karakteristik & Jumlah (n) & Persentase (\%) \\
\hline Usia & & \\
$\quad$ Lansia muda 60-69 thn & 28 & 77,78 \\
$\quad$ Lansia tua >70 thn & 8 & 22,22 \\
Jenis Kelamin & & \\
$\quad$ Laki-laki & 36 & 100 \\
$\quad$ Perempuan & 0 & 0 \\
Suku & & \\
$\quad$ Jawa & 6 & 16,67 \\
$\quad$ Sunda & 17 & 47,22 \\
$\quad$ Betawi & 4 & 11,11 \\
$\quad$ Batak & 2 & 5,56 \\
$\quad$ Tionghoa & 3 & 8,33 \\
$\quad$ Lainnya & 4 & 11,11 \\
\hline
\end{tabular}

Tabel 2. Kekerasan Fisik

\begin{tabular}{lcc}
\hline Kekarasan Fisik & Jumlah $(\mathbf{n})$ & Presentase (\%) \\
\hline Ya & 15 & 41,67 \\
Tidak & 21 & 58,33 \\
\hline
\end{tabular}

Tabel 3. Kekerasan Fisik Berdasarkan Usia

\begin{tabular}{llclc}
\hline \multirow{2}{*}{ Kekerasan Fisik } & \multicolumn{3}{c}{ Lansia muda } & Lansia tua \\
\cline { 2 - 5 } & $\mathbf{( n )}$ & $(\mathbf{\%})$ & $\mathbf{( n )}$ & $\mathbf{( \% )}$ \\
\hline Ya & 10 & 35,71 & 5 & 62,5 \\
Tidak & 18 & 64,29 & 3 & 37,5 \\
Total & 28 & 100 & 8 & 100 \\
\hline
\end{tabular}


Tabel 4. Kekerasan Fisik Berdasarkan Suku

\begin{tabular}{lcccc}
\hline \multirow{2}{*}{ Suku } & \multicolumn{2}{c}{ Terjadi Kekerasan } & \multicolumn{2}{c}{ Tidak terjadi kekerasan } \\
\cline { 2 - 5 } & $(\mathbf{n})$ & $(\boldsymbol{\%})$ & $(\mathbf{n})$ & $(\boldsymbol{\%})$ \\
\hline Jawa & 2 & 33,33 & 4 & 66,67 \\
Sunda & 9 & 52,94 & 8 & 47,06 \\
Betawi & 1 & 25 & 3 & 75 \\
Batak & 0 & 0 & 2 & 100 \\
Tionghoa & 2 & 66,67 & 1 & 33,33 \\
Lainnya & 1 & 25 & 3 & 75 \\
\hline
\end{tabular}

Tabel 5. Kekerasan Psikologis Berdasarkan Usia

\begin{tabular}{lcc}
\hline Kekerasan Psikologis & Jumlah $(\mathbf{n})$ & Presentase $(\boldsymbol{\%})$ \\
\hline Ya & 13 & 36,11 \\
Tidak & 23 & 63,89 \\
Total & 36 & 100 \\
\hline
\end{tabular}

Tabel 6. Kekerasan Psikologis Berdasarkan Usia

\begin{tabular}{lcccc}
\hline \multirow{2}{*}{ Kekerasan Psikologis } & \multicolumn{2}{c}{ Lansia muda } & \multicolumn{2}{c}{ Lansia tua } \\
\cline { 2 - 5 } & $\mathbf{( n )}$ & $(\boldsymbol{\%})$ & $\mathbf{( n )}$ & $(\boldsymbol{\%})$ \\
\hline Ya & 10 & 35,71 & 3 & 37,5 \\
Tidak & 18 & 64,29 & 5 & 62,5 \\
Total & 28 & 100 & 8 & 100 \\
\hline
\end{tabular}

Tabel 7. Kekerasan Psikologis Berdasarkan Suku

\begin{tabular}{lcccc}
\hline \multirow{2}{*}{ Suku } & \multicolumn{2}{c}{ Terjadi Kekerasan } & \multicolumn{2}{c}{ Tidak terjadi kekerasan } \\
\cline { 2 - 5 } & $\mathbf{n}$ & $\boldsymbol{0}$ & $\mathbf{n}$ & $\mathbf{\%}$ \\
\hline Jawa & 0 & 0 & 6 & 100 \\
Sunda & 8 & 47,06 & 9 & 52,94 \\
Betawi & 1 & 25 & 3 & 75 \\
Batak & 1 & 50 & 1 & 50 \\
Tionghoa & 1 & 33,33 & 2 & 66,67 \\
Lainnya & 2 & 50 & 2 & 50 \\
\hline
\end{tabular}

\section{Pembahasan}

Peneliti menemukan bahwa narapidana lansia di lembaga pemasyarakatan Jawa Barat yang mengalami kekerasan fisik sebesar $41,67 \%$. Miller (2012) menyatakan bahwa kualitas hidup lansia terjadi apabila ada penurunan kekerasan. Penelitian Sørensen, Kruse, Gudex HelwegLarsen, dan Brønnum-Hansen (2012) menyatakan bahwa terdapat hubungan antara kekerasan fisik dengan kualitas hidup individu. Wallace et al. (2008) menyebutkan salah satu area yang memengaruhi kualitas hidup adalah fisik individu. Hal tersebut menyimpulkan bahwa terjadi penurunan kualitas hidup pada narapidana lansia karena kekerasan fisik yang terjadi.

Faktor pemicu terjadinya kekerasan fisik pada lansia di lembaga pemasyarakatan yaitu adanya penurunan fisik. Peneliti menemukan beberapa lansia sudah mengalami penurunan tingkat mobilisasi, pendengaran, penglihatan dan penurunan integritas kulit. Penelitian mengenai hu- 
bungan antara penurunan fisik dengan terjadinya kekerasan menghasilkan kesimpulan bahwa lansia yang mengalami penurunan fisik berpeluang lebih besar terjadinya kekerasan (Lachs, Berkman, Fulmer, \& Horwitz, 2014).

Pemicu terjadinya kekerasan fisik pada narapidana lansia lainnya adalah susunan kehidupan. Susunan kehidupan yang berisiko terjadinya kekerasan apabila kurangnya privasi dan kondisi yang terlalu ramai. Kondisi lembaga pemasyarakatan yang dihuni oleh banyak narapidana dengan fasilitas yang digunakan bersama-sama mengurangi tingkat privasi individu, selain itu berdasarkan data yang didapat dari sistem database pemasyarakatan bulan Juli, lembaga pemasyarakatan Bogor, Bekasi, dan Cibinong merupakan lapas yang memiliki penghuni lebih dari kapasitas.

Jumlah narapidana yang melebihi kapasitas sangat berpotensi terjadinya kekerasan fisik pada lansia. Pemicu lainnya yang mengakibatkan kekerasan pada narapidana lansia adalah latar belakang narapidana, terutama mengenai tindakan kriminal yang telah dilakukan. Masalah-masalah seperti kekerasan pada narapidana terjadi karena latar belakang yang buruk, tingkat pendidikan yang rendah, peminum alkohol dan pengguna obat-obatan, dan membatasi diri dari pelayanan kesehatan terutama ketika muda (Keohane, et al., 2008).

Pencegahan yang dilakukan dapat bersifat pengawasan dari pertugas lapas dan pengelompokan narapidana lansia dalam satu sel. Lembaga pemasyarakatan dapat melakukan pengelompokan khusus lansia ketika melakukan kegiatan pribadi, seperti antrian lansia saat makan. Tindakan lain yang dapat dilakukan adalah pemasangan poster mengenai lansia, seperti poster menghormati lansia, poster pelarangan kekerasan pada lansia dan lain sebagainya. Kementrian Hukum dan HAM dapat menjaga kestabilan kapasitas lembaga pemasyarakatan, karena salah satu penyebab terjadinya kekerasan adalah jumlah penghuni yang melebihi kapasitas (Hartati, 2006).
Kejadian kekerasan psikologis pada narapidana lansia sebesar $36,11 \%$. Pernyataan mengenai kesedihan dan kesepian berisiko adanya kekerasan psikologis. Penelitian Daphne (2010) mengenai hubungan antara rasa kesepian dan tingkat terjadinya kekerasan, didapatkan kesimpulan bahwa lansia yang mengalami rasa kesepian dapat terjadi kekerasan fisik dan psikologis. Faktor lain yang menyebabkan kesedihan dan kesepian adalah keterbatasan berinteraksi dengan keluarga dan dunia luar. Hicks (2000) menyatakan bahwa kesepian yang terjadi pada lansia akan meningkat apabila berkurangnya hubungan dengan kerabat; meningkatnya ketergantungan; dan hilangnya teman, rumah, kebebasan dan identitas diri. Pemicu lainnya yang menyebabkan kesepian pada narapidana lansia adalah kurangnya aktivitas dan hubungan dengan narapidana lainnya. Kurangnya hubungan yang memuaskan termasuk pada orang-orang sekitar dapat memengaruhi rasa kesepian pada lansia (Miller, 2012).

Responden sebagian besar lebih banyak menghabiskan waktu dengan cara beribadah. Ibadah merupakan salah satu dari praktik kegamaan. Penelitian Mackenzie, et al. (2000) didapatkan bahwa agama dan praktik keagamaan dapat menjadi sistem pendukung spiritual individu. Menurut teori Fowler dalam Delune \& Ladner (2011) menyebutkan bahwa tahap perkembangan spiritual lansia berada pada universalizing faith atau umumnya individu merasa puas dengan kepercayaan yang dianutnya, pada tahap ini individu akan memelihara spiritualnya dengan cara melakukan praktik spiritual atau kegiatan sesuai yang dipercayainya.

Penelitian Hasnain, Ansari, dan Samantray (2011) menyimpulkan bahwa terdapat pengaruh yang signifikan antara spiritualitas dan kesejahteraan seseorang. Penelitian Bryant-Davis dan Wong (2013) didapatkan bahwa agama dan spiritual dapat menjadi strategi koping yang bisa memperbaiki trauma tiap individu. Peneliti menyimpulkan bahwa agama dan praktik spiritual yang dilakukan oleh lansia adalah strategi koping untuk mengatasi masalah fisik maupun 
psikologis yang dialami selama di lembaga pemasyarakatan.

Lembaga pemasyarakatan dapat memfasilitasi narapidana dalam praktik keagamaan dan meningkatkan nilai spiritual yang dimiliki sebagai cara pencegahan primer terhadap masalahmasalah yang dialami lansia, sesuai dengan teori Ladner dan Delune (2011) bahwa fase rehabilitasi harus memperhatikan aspek fisik, psikologis, dan dimensi spiritual. Lembaga pemasyarakatan dapat meningkatkan sarana ibadah, ceramah rohani, dan menghadirkan pemuka agama untuk meningkatkan kegiatan agama.

Pencegahan rasa kesepian dapat dila-kukan dengan cara membuat jadwal yang ter-atur untuk kegiatan lansia selama di lapas, selain itu diadakannya pemanggilan keluarga bagi narapidana lansia yang belum pernah atau sedikit frekuensinya dikunjungi oleh keluarga. Psikolog lapas dalam hal ini dapat melakukan konseling rutin agar masalah-masalah psikologis lansia dapat diatasi sesuai dengan penyebabnya.

Hasil penelitian menunjukkan kejadian kekerasan fisik pada narapidana lansia dengan kategori muda sebesar $35,71 \%$, sedangkan kejadian kekerasan fisik dengan kategori lansia tua sebesar $62,5 \%$. Hal tersebut karena penambahan usia pada individu dapat meningkatkan tingkat resiko terjadinya masalah kesehatan termasuk kekerasan (Stanhope \& Lancaster, 2004; Potter \& Perry, 2009).

Efek perubahan fisik karena penambahan usia secara umum adalah penurunan mekanisme homeostatik dan penurunan respon imunologik (Stanhope \& Lancaster, 2004). Proses penuaan yang terjadi pada lansia mengakibatkan penurunan kemampuan fungsional lansia (Miller, 2012). Penelitian mengenai hubungan antara penurunan fisik dengan terjadinya kekerasan menghasilkan kesimpulan bahwa lansia yang mengalami penurunan fisik berpeluang lebih besar terjadinya kekerasan (Lachs, Berkman,
Fulmer, \& Horwitz, 2014). Penurunan kemampuan fungsional dapat memengaruhi kualitas hidup seseorang Astuti (2013) dalam Lastiti (2014). Lembaga pemasyarakatan dapat melakukan pemantauan kesehatan secara berkala oleh tenaga kesehatan lapas untuk meningkatkan kualitas hidup lansia.

Penelitian mengenai kekerasan psikologis pada narapidana lansia bahwa lansia dengan kategori muda terjadi kekerasan sebesar 25,8\% dan lansia tua sebesar 37,5\%. Nazir (2006) menyatakan bahwa penduduk dengan usia $>75$ tahun mempunyai kualitas hidup yang lebih rendah dibandingkan dengan usia dibawahnya.

Teori Erikson dalam perkembangan psikologis menempatkan lansia pada tahap integritas dan keputusasaan. Pada tahap ini jika lansia memiliki harpan yang tidak sesuai dengan ekspektasi maka akan menimbulkan ketidaberdayaan. Ketidakberdayaan tersebut menimbulkan berbagai masalah kesehatan (Delune \& Ladner, 2011).

Psikolog dan perawat lapas sangat berperan penting dalam pencegahan dan penyembuhan kekerasan psikologis lansia. Proses pencegahan terjadinya kekerasan dengan cara promosi kesehatan mental seperti meningkatkan hubungan kekerabatan antara narapidana dengan kegiatankegiatan lapas. Cara pencegahan lain dengan mendeteksi koping yang dapat dilakukan lansia terhadap masalah psikologis yang dapat dihadapinya.

Tionghoa adalah suku yang mengalami kekerasan fisik paling besar yaitu $66,67 \%$. Hasil penelitian ini sesuai dengan konsep vulnerable population bahwa etnik minoritas sangat potensial terjadinya masalah kesehatan termasuk kekerasan. Terjadinya kekerasan berdasarkan suku dapat mengindikasikan adanya sebuah penolakan budaya. Menurut Leininger dan McFarland dalam Potter dan Perry (2006) menyebutkan bahwa penolakan budaya terjadi apabila individu memiliki pengalaman negatif dengan budaya baru atau berbeda. Penelitian yang di- 
lakukan Samsun (2005) mendapatkan data bahwa dalam lapas terdapat pengelompokan etnik yang menimbulkan konflik.

Lembaga pemasyarakatan perlu menerapkan manajemen konflik etnik yang tepat untuk mencegah terjadinya masalah ini. Manajemen konflik etnik dengan cara pemberian edukasi kepada narapidana, selain itu pertugas melakukan perhatian yang ketat terhadap narapidana lansia denga etnik minoritas. Lembaga pemasyarakatan dapat menghadirkan budayawan untuk melakukan pencegahan dengan mengkaji sinyal-sinyal konflik antar suku di lembaga pemasyarakatan.

Suku bangsa Batak (50\%) adalah suku dengan kekerasan psikologis terbesar daripada suku lainnya yang diteliti. Suku bangsa sunda yang merupakan suku mayoritas di lembaga pemasyarakatan Jawa Barat justru mengalami kekerasan lebih besar dibandingkan dengan suku lainnya. Peneliti menganalisis bahwa banyak faktor pemicu yang menyebabkan kekerasan psikologis pada narapidana lansia suku sunda. Faktor pertama adalah Suku Sunda paling banyak berada pada kategori lansia tua, hal ini sesuai dengan kekerasan psikologis pada lansia tua lebih tinggi dibandingkan pada lansia muda. Faktor lainnya adalah budaya sunda yang lebih tertutup misalnya budaya pamali. Penutupan diri tersebut dapat memicu terjadinya masalah psikologis lebih besar lagi.

\section{Kesimpulan}

Kesimpulan dari penelitian ini adalah karakteristik lansia pada penelitian ini sebagian besar berada pada kelompok lansia muda, berjenis kelamin laki-laki dan berasal dari suku sunda. Narapidana yang mengalami kekerasan fisik sebesar $41,67 \%$ dan narapidana yang mengalami kekerasan psikologis sebesar $36,11 \%$. Narapidana dengan kategori lansia tua lebih banyak terjadi kekerasan fisik daripada lansia dengan kategori muda. Narapidana dengan suku Sunda paling banyak terjadi kekerasan psikologis, dan narapidana suku Sunda dan
Tionghoa paling banyak terjadi kekerasan fisik (INR, ER, PN).

\section{Referensi}

American Psychological Association. (2012). Elder Abuse \& Neglect: in search of solution. Washington, DC: American Psychological Association.

Benjamin, A. E, Matthias, R. E., (2013). Health \& Social Work: Abuse and neglect of clients in agency-based and consumer-directed home care. Silver Spring: Oxford University Press. Tersedia di Basis data tesis dan disertasi ProQuest. (ProQuest document ID: 2105492 32).

Bryant-Davis, T., \& Wong, E.C. (2013). Faith to move mountains: religious coping, spirituality, and interpersonal trauma recovery. American Psychologist, 68 (8), 675-684.

Luoma, M.-L., Koivusilta, M., Lang, G., Enzenhofer, E., De Donder, L., Verté, D., Reingarde, J., Tamutiene, I., Ferreira-Alves, J., Santos, A.J. \& Penhale, B. (2011). Prevalance study of abuse and violance against older women: Results of a multicultural survey conducted in Austria, Belgium, Finland, Lithuania, and Portugal (European report of the AVOW project). Finland: National Institute for Health and Welfare (THL).

DeLaune, S.C., Ladner, P.K. (2011). Fundamentals of nursing: Standards \& practice (4th Ed.). Canada: Cengage Learning.

Hasnain, N., Ansari, S.A., \& Samantray, S. (2011). Spirituality and happiness as correlates of well-being in religious women. European Journal of Social Sciences, 20 (3), 431-442.

Hartati, H. (2006). Budaya Kekerasan dalam Lembaga Pemasyarakatan (Tesis, Program Studi Magister Fakultas Ilmu Sosial dan Politik Universitas Indonesia). Depok: Perpustakaan Pusat Universitas Indonesia

Hicks, T.J.Jr. (2000). What is your life like now?: Loneliness and elderly individuals residing in 
nursing homes. J Gerontol Nurs, 26 (8), 1519.

Kementrian Kesehatan RI. (2013). Buletin jendela: Data dan informasi kesehatan. Jakarta: Kementrian Kesehatan RI.

Keohane, P., Lax, G., Sed, C., Sterns, A., \& Sterns, R. (2008). The growing wave of older prisoners: A national survey of older prisoner health, mental health and programming. Lanham: American Correctional Association, Inc.

Keigher, S.M. (Ed.). (1991). Housing risks and homelessness among the urban elderly. New York: The Haworth Press, Inc.

Kosberg, J.I., \& ACSW. (2008). The abuse of elderly men. Journal of Elder Abuse \& Neglect, 9 (3), 69-88. doi: 10.1300/J084v09n 03_04.

Lachs, M.S., Berkman, L., Fulmer, T., \& Horwitz, R.I. (1994). A prospective community-based pilot study of risk factors for the investigation of elder maltreatment. Journal of the American Geriatrics Society, 42 (2), 169 173.

Lachs, M.S., \& Pillemer, K. (2014). Abuse an neglect of elderly persons. $N$ Engl $\mathrm{J} \mathrm{Med}$, 332, 437-443. doi: 10.1056/NEJM19950216 3320706 .

Lastiti, L. (2014). Hubungan salah perlakuan pada lansia dengan kualitas hidup lansia dalam keluarga di Kelurahan Curug, Cimanggis (Skripsi, tidak dipublikasi). Fakultas Ilmu Keperawatan Universitas Indonesia, Depok.

Liwarti, L. (2013). Hubungan pengalaman spiritual dengan psychological well being pada penghuni lembaga pemasyarakatan. Jurnal Sains dan Praktik Psikologi, 1 (1), 77-88.

Mackenzie, E.R., Rajagopal, D.E., Meibohm, M., \& Lavizzo-Mourey, R. (2000). Spiritual support and psychological well-being: older adults' perceptions of the religion and health connection. Altern Ther Health Med, 6 (6), $37-45$.
McDonald, L. (2011). Elder abuse and neglect in Canada: The glass is still half full. Can $J$ Aging, 30 (3), 437-465. doi: 10.1017/S07149 80811000286 .

Miller, C.A. (2012). Nursing for wellness in older adults (6th Ed.). Philadephia: J.B. Kippincot Company.

Nazir, K.A. (2006). Penilaian kualitas hidup pasien pasca bedah pintas koroner yang menjalani rehabiitasi fase III dengan menggunakan SF36 (Tesis Master, Program Studi Magister Universitas Indonesia). Jakarta: Universitas Indonesia.

Potter, P.A., \& Perry, A.G. (2009). Fundamental of nursing: Concept, process and practice (7th Ed.). St. Louis, Missouri: Mosby-Elsevier.

Pusat Data dan Informasi. (2008). Jumlah penyandang masalah kesejahteraan sosial menurut kriteria lanjut usia terlantar (Kabupaten/Kota). Diperoleh pada tanggal 27 November 2014. http://dbyanrehsos.Dep sos.go.id $/$ map.php? mode $=$ pmks\&p=11\&iid= 206

Samsun, S. (2005). Kebijakan dan manajemen pencegahan dan penyelesaian etnis narapidana (Tesis, Program Pascasarjana Universitas Indonesia). Depok: Perpustakaan Universitas Indonesia.

Singh, R.S. (2014). Elderly abuse and neglect: The challenges ahead. Indian Journal of Health and Wellbeing, 5 (3), 398-401.

Stanhope, M., \& Lancaster, J. (2004). Community \& public health nursing (6th Ed.). (Penerjemah: N. Juniarti, S. Kurniangsih). Jakarta: EGC.

Sørensen, J., Kruse, M., Gudex, C., Helweg-Larsen, K., \& Brønnum-Hansen, H. (2012). Physical violence and health-related quality of life: Danish cross-sectional analyses. Health Qual Life Outcomes, 10, 113. doi: 10.1186/14777525-10-113

Wallace, L.S., Rogers, E.S., \& Weiss, B.D. (2008). Relationship health literacy and healthrelated quality of life among Tennesseans. Tenn Med, 101 (5), 35-39. 